DOI No: http://dx.doi.org/10.29228/Joh.51733

Authenticity process is conducted by

Makale Türü: Araştırma makalesi

Geliş Tarihi: 11-06-2021

Kabul Tarihi: $12-08-2021$

On-line Yayın: 31-08-2021

Article Type: Research article Submitted: 11-06-2021

Accepted: $12-08-2021$

Published Online: 31-08-2021

Attf Bilgisi / Reference Information

Ustabulut, M.Y. (2021). Investigation Pre-Service Turkish Language Teachers' Curiosity and Exploring Levels In Terms of Some Variables. Journal of History School, 53, 2496-2511.

\title{
INVESTIGATION PRE-SERVICE TURKISH LANGUAGE TEACHERS' CURIOSITY AND EXPLORING LEVELS IN TERMS OF SOME VARIABLES ${ }^{1}$
}

\begin{abstract}
Mete Yusuf USTABULUT ${ }^{2}$
Abstract

This research is aiming to analyze the curiosity and the level of exploring and the changing effects of this level for the pre-service Turkish language teachers. Survey model, which is one of the quantitative research designs, was used in the research. Target population of the research constitutes the students from the Department of Turkish Education in University of Bayburt. As data collection tool Curiosity and Exploring Scope II and to determine the socio-demographic quality of the students Personal Information Form (PIF) was used. Data of the research were collected online on a voluntary basis. Inferential quantitative statistics were used in the analysis of the data. Since the data set, which was acquired in the survey, didn't ensure normal distribution nonparametric tests Whitney $U$ and Kruskal Wallis were used in the in the analysis of data. In the consequence of the survey curiosity and level of exploring of the pre-service teachers weren't discovered any differences according to their genders, class grades, ages, and education level of their parents, income level of their families and geographical area they live in.
\end{abstract}

Keywords: Curiosity and Exploring, Pre-Service Turkish Language Teachers, Turkish Language Education.

\footnotetext{
${ }^{1}$ The ethics committee decision of this article was given by the Dean of the Faculty of Education of Bayburt University with the number E-79126184-050.99-3848 dated 29.01.2021.

${ }^{2}$ As. Prof, Bayburt University, Department of Turkish Education, meteustabulut@bayburt.edu.tr, Orcid: 0000-0002-8864-645X
} 
Investigation Pre-Service Turkish Language Teachers' Curiosity Levels in Terms of...

\section{Türkçe Öğretmen Adaylarının Merak ve Keşfetme Düzeylerinin Bazı Değişkenler Açısından İncelenmesi}

$\ddot{\mathbf{O} z}$

$\mathrm{Bu}$ araştırmanın amacı Türkçe öğretmen adaylarının merak ve keşfetme düzeylerini ve bu düzeylerini etkileyen değişkenleri incelemektir. Araştırmada nicel araştırma desenlerinden tarama (survey) modeli kullanılmıștır. Araştırmanın çalıșma evrenini Bayburt Üniversitesi Türkçe Eğitimi Bölümü öğrencileri oluşturmaktadır. Araştırmada veri toplama aracı olarak Merak ve Keşfetme Ölçeği II ve öğrencilerin sosyo-demografik niteliklerini belirlemek amacıyla Kişisel Bilgi Formu (KBF) kullanılmıştır. Araştırma verileri, gönüllülük esasına dayalı olarak çevrimiçi olarak toplanmıştır. Verilerin analizinde anlam çıkarıcı nicel istatistikler kullanılmıştır. Araştırmada elde edilen veri seti normal dağılım sağlamadığı için verilerin analizinde parametrik olmayan testlerden Mann-Whitney U ve Kruskal Wallis testi kullanılmıştır. Araştırma sonucunda öğretmen adaylarının merak ve keşfetme düzeylerinin cinsiyet, sınıf düzeyi, yaş, anne ve baba eğitim düzeyi, ailelerin gelir düzeyi ve yaşanılan coğrafi bölgeye açısından farklılaşmadığı bulgulanmıştır.

Anahtar Kelimeler: Merak ve Keşfetme, Türkçe Öğretmen Adayı, Türkçe Eğitimi.

\section{INTRODUCTION}

Used in the meaning of "desire for acquiring new information" (Renner, 2006) curiosity affects learning, acquiring information and completing lifetime. From this aspect this can be said that curiosity is an essential human motivation (Kashdan, et al., 2020). W. James described curiosity as an instinctual such as; hunting, toolmaking and love. According to Spielberger and Reheiser (2009) W. James was strongly impressed by Darwin's (2001) opinions about evolutionary theory. Thus W. James presented an instinctual curiosity theory. Accordingly, the topic is there's an attraction for new stimulants since it eases to survive. In spite of that the anxiety, which awakes from new circumstances, is usually impeding curiosity. As a conclusion William James stated contrary relationship which ending up when curiosity and anxiety appears at the same time, like Freud.

Curiosity, which is a miracle of human's mind, is a boosting force both for individuals and for societies' learning and in providing inner vision (Lindholm, 2018). The effect of curiosity over learning was emphasized in the definitions made. So that curiosity is an effective reason for students to teach subjects easily (Elban, 2017). On the other hand, curiosity is crucial for children's cognitive development. However, there's not any definition to explain children's curiosity (Jirout and Klahr, 2011) 
In a sense, individuals' constant deep desire for learning and knowing for a self actualization and wanting to feed with new information this unappeased desires is defined as 'deep epistemic curiosity (Kang et al., 2009; Leslie, 2014). When it's analyzed about curiosity concept different dimensions can be seen (Acun, Kapıkıran and Kabasakal, 2013). For instance; curiosity arising from impulses and decreasing by discovering is perceptive curiosity, desiring to acquire a knowledge is epistemic curiosity and relieving boredom or a special curiosity based on needing arousal for a specific area, these are can be sorted as different kinds of curiosity (Berlyne, 1954. cited Jirout and Klahr, 2011). Social curiosity (Renner, 2006; Kashdan, et al., 2020) and a situational and continuous curiosity based on a special moment and emotions related with general situations of individuals' (Spielberger and Butler, 1971; Spielberger, Peters and Frain, 1976) These are can be exemplified for different kinds of curiosity.

Another classification for curiosity is 'good curiosity' and 'bad curiosity' which was classified by David Hume (Hume, 2009, p.301)

Alongside the affection of knowledge which presented himself in the science, there's a significant curiosity which is engrafted to human nature and this curiosity is a passion arising from absolutely different principle. Some people have an insatiable desire to know their neighbours' actions and stiuations although the benefits don't interest them and they need to be depended on others and in this case there's no room for analyze and self-commitment.

According to Hume (2009) the subject is the distinction between good curiosity which is expressing the affection of science and bad curiosity which is the desire to know the things that are not related a person's himself. It's seen that distinction between "good curiosity" and "bad curiosity" which was defined by Hume also defined by Selim Sirr Bey who was one of the educators of Ottoman and Republic period. Accoridng to Selim Sirrı, wherease good curiosity increases individual's knowledge and moral, bad curiosity harms individual in terms of spiritually and intellectually. Selim Sirr1 explained the bad curiosity as below (Elban, 2019):

... Figuring out everyone's secret is a bad nature. What is happening at neighbour's house? What's cooking in their kitchens? What is there in their closet? Trying to finding out these is a fault. Learning someone's insist is an immorality, announcing and disclosing it is a meanness. It's a kind of disease for some people to know others conditions. They surveil from the keyhole to see what two people are doing behind the door or they come close to hear what they are talking about. This is a hateful curiosity that we need to avoid, there's not any difference than working as a detective or a spying work. Another bad curiosity is to learn others' shame. This is kind 
Investigation Pre-Service Turkish Language Teachers' Curiosity Levels in Terms of...

of pleasure for many people. There're also people who regard to know other's secret is a kind of achievement however this is a destituteness. It's a must to be away from those people and not to pay heed to their sayings.

As it's seen that curiosity was regarded differently in different cultures during the history. It can be said that curiosity was regarded sometimes as value or sometimes as the reason of malignity (as cited in Lindholm, 2018).

It's necessary to look up domestic researches when we consider the importance of curiosity in education. It's seen that researches about curiosity have been on the focusing topic in Turkey for 15 years in. However, the research that Elban did (2019) proved that some researches about the concept of curiosity on education was discussed by Turkish educators before. Sat1 Bey and Sirr1 Tarcan, who were educators from Ottoman and Republic period, also discussed the concept of curiosity in terms of society and education.

On the other hand, effects of age, social class, gender studied program and universities over curiosity were also surveyed in the researches about curiosity (Acun, Kapıkıran and Kabasakal, 2013; Engelhard ve Monsaas, 1988; Ben-Zur ve Zeidner, 1988, Demirel ve Çoşkun, 2009; Litman and Spielberger, 2003; Şentürk, 2020; Kapıkıran and Kırmız1, 2019; Turan, 2015)

Neverthless, it was stated that mothers have protective attitudes in the lower social economic class families (Öğretir-Özçelik and Şıvkın, 2019). It is expresssed that individual's experiences and culture over curiosity is affected as well. (Kashdan, Rose and Fincham, 2004; Kashdan, et al., 2009; Lindholm, 2018; Elban, 2019). In addition to the family, teachers are also effective in curiosity and discovery. As a matter of fact, the child needs to know himself and acquire the necessary skills in terms of curiosity and discovery. Especially at school age, it is important for teachers to guide children to wonder and explore. There is a relationship between curiosity and discovery and acquiring knowledge. In other lessons and Turkish lessons, students' reading habits, self-expression and curiosity and discovery tendencies in terms of written culture are developed. For this reason, it is valuable to determine the pre-professional curiosity and discovery levels of Turkish teacher candidates and to eliminate deficiencies, if any.

This research is aiming to analyze the curiosity and the level of exploring and the changing effects of this level for the pre-service Turkish language teachers. Within this scope problems of this research were planned as followings:

1. Is there any difference in the level of curiosity and exploring according to their genders of pre-service Turkish language teachers? 
2. Is there any difference in the level of curiosity and exploring according to their social classes of pre-service Turkish language teachers?

3. Is there any difference in the level of curiosity and exploring according to their ages of pre-service Turkish language teachers?

4. Do pre-service Turkish language teachers 'curiosity and exploring differ from according to their mothers' education level?

5. Do pre-service Turkish language teachers 'curiosity and exploring differ from according to their fathers' education level?

6. Do pre-service Turkish language teachers' curiosity and level of exploring differ from according to their families' level of incomes?

7. Do pre-service Turkish language teachers 'curiosity and exploring differ from according to the geographical area they live?

\section{METHODOLOGY}

\section{Research Model}

This research is a study which was written in survey model aiming to analyze the curiosity and the level of exploring of pre-service Turkish language teachers. Surveys aim to describe the existed past situations with the present situations. Surveys are models which aims to attain genel judgements from a targer population which consisted of numerous. In some cases, it reaches general judgements by getting information from the whole target populationor via a group of people in the universe (Karasar, 2000, p.20).

\section{Research Sample}

The target population of the study constitutes students from the University of Bayburt in the department of Turkish Language Education. It was tried to attain all the target population by not doing sample survey. Information about target population was submitted in the table 1 . As it can be seen in the table 1,67.3\% of the participant are female, $32 \%$ are male, $1.9 \%$ of the participants in the study are in the preparatory class, $35.5 \%$ of them are freshmen, $24.3 \%$ are sophomore, $25.2 \%$ are junior and $13.1 \%$ are senior. $4.7 \%$ of pre-service teachers who were practiced in terms of age. $15 \%$ are nineteen years old, $18.7 \%$ are twenty years old, $28 \%$ are twenty-one years old and $33.6 \%$ are twenty-two and over. $19.6 \%$ of the mothers of the participants are not able to read and write. The remainder is $46.7 \%$ primary school graduates, $17.8 \%$ secondary school graduates, $4.7 \%$ high school graduates, $8.4 \%$ university graduates and $2.8 \%$ have master degree. $6.5 \%$ 
Investigation Pre-Service Turkish Language Teachers' Curiosity Levels in Terms of...

of the fathers of the participants are not able to read and write. The remainder is $42.1 \%$ primary school graduates, $23.4 \%$ secondary school graduates, $12.1 \%$ high school graduates, $13.1 \%$ university graduates and $2.8 \%$ graduates. $9.3 \%$ of the participants' families 0 - $750 \mathrm{TL}, 15 \% 751$ - $1500 \mathrm{TL}, 21.5 \% 1501$ - $2500 \mathrm{TL}$, $11.2 \% 2501-3000$ TL, $21.5 \%$ They have a monthly income of 3001 TL and 4000 TL and 21.5 of them 4001 TL and above. $16.8 \%$ of the students participating in the study are in the Central Anatolia Region, 5.6\% in the Marmara Region, 15\% in the Black Sea Region, $8.4 \%$ in the Aegean Region, +12.1 of them lived in the Mediterranean Region, $16.8 \%$ in the Eastern Anatolia Region and 25.2\% in the Southeastern Anatolia Region before entering the university.

\section{Data Collection Tools and Procedure}

In the research curiosity and exploring scale II was used (Kashan et al., 2009). Also Personal Information Form (PIF) was used in order to determine students' socio-demographic qualities. Data of this survey was obtained based on voluntariness online environment. In order to evaluate the level of curiosity and exploring of the participated students Curiosity and Exploring Scope CES-II was used this was developed by Kashdan et al., (2009) and it was adapted to Turkish culture by Acun, Kap1kiran, \& Kabasakal (2013). The scope, which is consisted of 10 issues, has two sub dimensions (flexibility and accepting the uncertainty). The scope, which has 3.80 eigenvalue in the flexibility dimension, $38.01 \%$ announced variation and in the accepting the uncertainty dimension 1.23 eigenvalue, \%12.33 announced variation, the total variation is \%50.33. It was discovered that Cronbach Alfa coefficient for the whole $\operatorname{scope}(\alpha=.81)$, for the flexibility factor $(\alpha=.81)$, for the accepting the uncertainty $(\alpha=.68)$. It's shown that the fit indices with two factors model is verified $(\chi 2(34, \mathrm{~N}=337)=69.41$, $\mathrm{p}<.001 ; \mathrm{RMSEA}=.05, \mathrm{SRMR}=.04, \mathrm{CFI}=98, \mathrm{NNFI}=.97)$.

\section{Data Analysis}

It was looked upon if the data's distribution normal or not in the selection of analyzes which are parametric and nonparametric in the analyzes which were done. Although the values are in the acceptable level with the data warp $(-0,858)$ and kurtosis (2.378), nonparametric tests were preffered since the KolmogorovSmirov value $\mathrm{p}=.00<.05$ is small (Tabachnick and Fidell, 2019; Seçer, 2015). 
Table 1.

Demographic Information about those who Participated the Survey.

\begin{tabular}{|c|c|c|c|}
\hline & Subgroups & $\mathbf{n}$ & $\%$ \\
\hline \multirow[t]{2}{*}{ Gender } & Female & 72 & 67,3 \\
\hline & Male & 35 & 32,7 \\
\hline \multirow[t]{5}{*}{ Class Grade } & Prep class & 2 & 1,9 \\
\hline & Freshmen & 38 & 35,5 \\
\hline & Sophomore & 26 & 24,3 \\
\hline & Junior & 27 & 25,2 \\
\hline & Senior & 14 & 13,1 \\
\hline \multirow[t]{5}{*}{ Age } & 18 & 5 & 4,7 \\
\hline & 19 & 16 & 15,0 \\
\hline & 20 & 20 & 18,7 \\
\hline & 21 & 30 & 28,0 \\
\hline & 22 and over & 36 & 33,6 \\
\hline \multirow[t]{6}{*}{ Education level of mother } & Illiterate & 21 & 19,6 \\
\hline & Primary school graduate & 50 & 46,7 \\
\hline & Middle school & 19 & 17,8 \\
\hline & High school graduate & 5 & 4,7 \\
\hline & University graduate & 9 & 8,4 \\
\hline & Master's degree & 3 & 2,8 \\
\hline \multirow{6}{*}{ Education level of father } & Illiterate & 7 & 6,5 \\
\hline & Primary school graduate & 45 & 42,1 \\
\hline & Middle school & 25 & 23,4 \\
\hline & High school graduate & 13 & 12,1 \\
\hline & University gradute & 14 & 13,1 \\
\hline & Master's degree & 3 & 2,8 \\
\hline \multirow[t]{6}{*}{ Montly incomes of your family } & $0-750 \mathrm{TL}$ & 10 & 9.3 \\
\hline & $751-1500 \mathrm{TL}$ & 16 & 15 \\
\hline & $1501-2500 \mathrm{TL}$ & 23 & 21,5 \\
\hline & $2501-3000 \mathrm{TL}$ & 12 & 11,2 \\
\hline & $3001-4000 \mathrm{TL}$ & 23 & 21,5 \\
\hline & 4001 TL ve üzeri & 23 & 21,5 \\
\hline \multirow{7}{*}{$\begin{array}{l}\text { The geographical region before } \\
\text { they started university }\end{array}$} & Central Anatolia Region & 18 & 16,8 \\
\hline & Marmara Region & 6 & 5,6 \\
\hline & Black Sea Region & 16 & 15 \\
\hline & Aegean Region & 9 & 8,4 \\
\hline & Mediterranean Region & 13 & 12,1 \\
\hline & East Anatolian Region & 18 & 16,8 \\
\hline & Southeastern Anatolia Region & 27 & 25,2 \\
\hline
\end{tabular}


Investigation Pre-Service Turkish Language Teachers' Curiosity Levels in Terms of...

\section{FINDINGS}

The table demonstrating the curiosity and level of exploring of pre-service Turkish language teachers according to their genders.

Table 2.

Mann-Whitney $\mathrm{u}$ test which Demonstrate Curiosity and Level of Curiosity Differences According to Genders.

\begin{tabular}{llcccc}
\hline Gender & $\mathbf{n}$ & Mean rank & Mean sum & $\mathbf{U}$ & $\mathbf{p}$ \\
\hline Female & 72 & 51,27 & 3691,50 & 1063.500 & .19 \\
Male & 35 & 59,61 & 2086,50 & \\
\hline As it can be seen on the table 2 the scores of students' curiosity and \\
exploring don't differ according to their genders (U=1063.500, p >,05). The \\
differences table of students' curiosity and exploring score according to their \\
class grades is demonstrated below.
\end{tabular}

Table 3.

Kruskal Wallis Test's Result of Curiosity and the Level of Exploring Differences according to Their Class Grade

\begin{tabular}{lccccc}
\hline Class Grade & n & Mean rank & sd & $\boldsymbol{\chi 2}$ & p \\
\hline Prep class & 2 & 54,00 & 4 & 8,54 &, 07 \\
Freshmen & 38 & 50,41 & & & \\
Sophomore & 26 & 69,19 & & & \\
Junior & 27 & 48,80 & & & \\
Senior & 14 & 45,57 & & & \\
\hline
\end{tabular}

As it can be seen on the table 3 students' curiosity and exploring scores don't differ much accoridng to their class grade $(\chi 2=8,54 ; \mathrm{p}>.05)$. The differences table of students' curiosity and exploring score according to their ages is demonstrated below.

Table 4.

Kruskal Wallis Test's Result of Curiosity and The Level of Exploring Differences According to Their Ages

\begin{tabular}{cccccc}
\hline Age & n & Mean rank & sd & $\chi^{2}$ & p \\
\hline 18 & 5 & 50,20 & 4 & 1,74 &, 78 \\
19 & 16 & 49,75 & & & \\
20 & 20 & 61,30 & & & \\
21 & 30 & 51,25 & & & \\
22 and over & 36 & 54,65 & & & \\
\hline
\end{tabular}


As it can be seen on the table 4 students' curiosity and exploring scores don't differ much according to their class grade $(\chi 2=1,74 ; \mathrm{p}>.05)$. The differences table of students' curiosity and exploring score according to their mothers' education level is demonstrated below.

As it can be seen on the table 5 students' curiosity and exploring scores don't differ much according to their mothers' level of education $(\chi 2=1,56$; $\mathrm{p}>.05)$. The differences table of students' curiosity and exploring score according to their fathers' education level is demonstrated below.

\section{Table 5.}

Kruskal Wallis Test's Result of Curiosity and The Level of Exploring Differences according to Their Mothers' Level of Education

\begin{tabular}{lccccc}
\hline Mother's education level & $\mathrm{n}$ & Mean rank & $\mathrm{sd}$ & $\chi^{2}$ & $\mathrm{p}$ \\
\hline Not able to write and read & 21 & 56,17 & 5 & 1,56 &, 91 \\
Primary graduated & 50 & 51,48 & & & \\
Middle school graduated & 19 & 52,26 & & & \\
High school graduated & 5 & 58,40 & & & \\
University graduated & 9 & 59,06 & & & \\
Master degree & 3 & 69,33 & & & \\
\hline
\end{tabular}

Table 6.

Kruskal Wallis Test's Result of Curiosity and The Level of Exploring Differences according to Their Fathers' Level of Education.

\begin{tabular}{lccccc}
\hline Father's education level & n & Mean rank & sd & $\boldsymbol{\chi 2}$ & $\mathbf{p}$ \\
\hline Not able to write and read & 7 & 54,93 & 5 & 9,05 &, 11 \\
Primary school graduate & 45 & 47,50 & & & \\
Middle school graduate & 25 & 62,54 & & & \\
High school graduate & 13 & 59,77 & & & \\
University graduated & 14 & 46,29 & & & \\
Master degree & 3 & 89,17 & & & \\
\hline
\end{tabular}

As it can be seen on the table 6 students' curiosity and exploring scores don't differ much according to their fathers' level of education $(\chi 2=9,05 ; p>.05)$. The differences table of students' curiosity and exploring score according to their families' income level is demonstrated below. 
Investigation Pre-Service Turkish Language Teachers' Curiosity Levels in Terms of...

\section{Table 7.}

Kruskal Wallis Test's Result of Curiosity and The Level of Exploring Differences according to Their Families' Income Level

\begin{tabular}{lccccc}
\hline Families' income level & n & Mean rank & sd & $\boldsymbol{\chi 2}$ & P \\
\hline $0-750$ TL & 10 & 64,40 & 5 & 3,40 & .64 \\
$751-1500$ TL & 16 & 53,25 & & & \\
$1501-2500$ TL & 23 & 50,28 & & & \\
$2501-3000$ TL & 12 & 64,63 & & & \\
$3001-4000$ TL & 23 & 52,72 & & & \\
4001 TL ve üzeri & 23 & 49,46 & & & \\
\hline
\end{tabular}

As it can be seen on the table 7 students' curiosity and exploring scores don't differ significantly according to their families' income level $(\chi 2=3,40$ $\mathrm{p}>.05)$. The differences table of students' curiosity and exploring score according to the geographical area they live is demonstrated below.

Table 8.

Kruskal Wallis Test's Result of Curiosity and The Level of Exploring Differences according to Geographical Area They Live in

\begin{tabular}{lccccc}
\hline Geographical area students live in & n & Mean rank & sd & $\boldsymbol{\chi 2}$ & p \\
\hline Central Anatolia Region & 18 & 43,81 & 6 & 6,46 &, 37 \\
Marmara Region & 6 & 52,83 & & & \\
Black Sea Region & 16 & 49,03 & & & \\
Aegean Region & 9 & 49,00 & & & \\
Mediterranean Region & 13 & 59,27 & & & \\
Eastern Antolia Region & 18 & 51,31 & & & \\
Southeastern Anatolia Region & 27 & 64,93 & & & \\
\hline
\end{tabular}

As it can be seen on the table 8 curiosity and exploring scores don't differ significantly according to the geographical area students live in $(\chi 2=3,40 \mathrm{p}>.05)$.

\section{CONCLUSION and DISCUSSION}

It was discovered that students' curiosity and level of exploring scores don't differ according to their genders. In terms of gender, it wasn't determined any different in the research that Engelhard and Monsaas (1988) did. In terms of gender, it wasn't found any difference in the level of curiosity and level of exploring of males in the first research Acun, Kapıkıran and Kabasakal (2013) 
did. Şentürk (2020) wasn't found significant difference according to gender variable. In spit of that it was determined that level of curiosity and exploring of males is higher than the score of females in the research Acun, Kapikiran, and Kabasakal did (2013).

And males' curiosity was explained by given more active roles for males. However, in terms of gender some discoveries made in support of males in many researches (Kapıkıran and Kırmızı, 2019; Ben-Zur and Zeidner, 1988, Demirel and Çoşkun, 2009; Litman and Spielberger, 2003; Turan, 2015). It can be said different results can be obtained in the research of curiosity and exploring in terms of gender. The discovery obtained in the research can be evaluated in different results too. It was anaylzed that if the curiosity and exploring score differ or not according to class grade. It was determined that candidate teachers' curiosity and exploring score don't differ according to their class grade. It's clear when it's analyzed related research's discovers about class grade parallel with the studies made before (Kapıkıran and Kırmız1, 2019; Turan, 2015). In terms of age of candidate Turkish language teachers' level of curiosity didn't differ. In terms of age of participations' level of curiosity differed in the Şentürk's (2020) research. However, it is thought that the fact that there are participants from every age group in the mentioned study is an explanation for the different findings obtained in the two studies.

It was determined that candidate teachers' parents' education level and also families' economic level didn't affect the curiosity level. Öğretir-Özçelik and Şıvkın (2019) stated that mothers from lower socio-economic families have protective attitudes. In this context it was though in this research that there's an effect of protective attitudes on curiosity, depending on socio-economic level. Based on this result, participants can end up protective attitudes of mothers in the later life or there's not any effect of protective attitudes on curiosity can be interpreted

In conclusion it was determined that there's not any effect of the geographical area students live in on curiosity. It's determined that the effect of the culture on curiosity. However, it can be explained by breaking the cultural influence in the place where it should not show this effect outside of geographical regions (Kashdan, Rose ve Fincham, 2004; Kashdan et all., 2009). On the other hand, cultural effect can be related with the other dimensions of curiosity.

Based on the results of the research, the following applications can be suggested: 
Investigation Pre-Service Turkish Language Teachers' Curiosity Levels in Terms of...

1) In the research, it was determined that the level of curiosity and discovery of the candidates varies according to the culture. During the undergraduate period, training should be given in accordance with the cultural characteristics of the teacher candidates. In this way, cultural characteristics should be used to develop curiosity and discovery skills.

2) It has been observed that variables such as gender, age and class have no effect on the level of curiosity and discovery. Other variables that affect the curiosity and discovery levels of teachers and candidates can be determined.

\section{REFERENCES}

Acun, N., Kapıkıran, Ş., \& Kabasakal, Z. (2013). Trait curiosity and exploration inventory-11: Exploratory and confirmatory factor analysis and its reliability. Türk Psikoloji Yazıları, 16(31), 74-85.

Ben-Zur, H., \& Zeidner, M. (1988). Sex differences in anxiety, curiousity, and anger: A cross-cultural study. Sex Roles, 19(5-6), 335-347.

Darwin, C. (2001). Insan ve Hayvanlarda Duygularin Ifadesi. (Trans. O. Tuncay). Gün Yayıncılık.

Demirel, M., \& Çoşkun, Y. D. (2009). Investigation of curiosity levels of üniversity students in terms of some variables. Mehmet Akif Ersoy Üniversitesi Eğitim Fakültesi Dergisi, 9(18), 111-134.

Elban, M. (2017). University students' views on the education and teaching of civilization history: Bayburt university education faculty sample. Journal of Education and Training Studies, 5(10), 123-136. https://doi.org/10.11114/jets.v5i10.2560

Elban, M. (2019). Sâtı Bey ve Selim Strrı Tarcan'da merak kavramı: Bir karşılaştırma. [Conference presentation]. IKSAD 4. International Congress of Social Sciences, IKSAD.

Engelhard, G., \& Monsaas, J.A. (1988). Grade level, gender and school-related curiosity in urban elementary schools. The Journal of Educational Research, 82(1), 22-26.

Hume, D. (2009). Insan Doğası Üzerine bir Inceleme. (Trans. E. Baylan). BilgeSu.

James, W. (1890). The Principles of Psychology, Vol. 2. Henry Holt and Company.https://doi.org/10.1037/11059-000 
Jirout, J., \& Klahr, D. (2011). Children's scientific curiosity: In search of an operational definition of an elusive concept. Developmental Review, 32, 125-160. https://doi.org/10.1016/j.dr.2012.04.002.

Kang, M. J., Hsu, M., Krajbich, I. M., Loewenstein, G., McClure, S. M., Tao-yi Wang, G., \& Camerer, C. F. (2009). The wick in the candle of learning: Epistemic curiosity activates reward circuitry and enhances memory. Psychological Science, 20, 963-973. https://doi.org/10.1111/j.14679280.2009.02402.x

Kapıkıran, Ş., \& Kırmızı, F.S. (2019). Öğretmen adaylarının merak ve keşfetme algıları ile okuma alışkanlığına yönelik tutumları arasındaki ilişki. Ahi Evran Üniversitesi Sosyal Bilimler Enstitüsü Dergisi, 5(2), 251-265. https://doi.org/10.31592/aeusbed.585328.

Karasar, N. (2000). Bilimsel Araştırma Yöntemi. Nobel Yayın.

Kashdan, T. B., \& Silvia, P. J. (2009). Curiosity and interest: The benefits of thriving on novelty and challenge. C. R. Synder ve S. J. Lopez, (Ed.), In Oxford Handbook of Positive Psychology (pp. 367-375). Oxford University Press.

Kashdan, T. B., Disabato, D. J., Goodman, F. R., \& McKnight, P. E. (2020). The Five-Dimensional curiosity scale revised (5DCR): Briefer subscales while separating overt and covert social curiosity. Personality and Individual Differences, 157, 1-10. https://doi.org/10.1016/j.paid.2020.109836.

Kashdan, T. B., Rose, P., \& Fincham, F. D. (2004). Curiosity and exploration: Facilating positive subjective experiences anda personal growth opportunities. Journal of Personality Assesment, 82(3), 291-305.

Leslie, I. (2014). Curious. The Desire to Know and Why Your Future Depends on it. Basic Books.

Lindholm, M. (2018). Promoting curiosity? Possibilities and pitfalls in science education. Science \& Education, 27(9-10), 987-1002. https://doi.org/10.1007/s11191-018-0015-7

Litman, J. A., \& Spielberger, C. D. (2003). Measuring epistemic curiosity and its diversive and specific components. Journal of Personality Assessment, 80(1), 75-86. https://doi.org/10.1207/S15327752JPA8001_16

Öğretir-Özçelik, A.D., \& Şıvkın, E. (2019). Investigation of mother attitudes in different sociaeconomic level in terms of various variables. Asya Studies- 
Investigation Pre-Service Turkish Language Teachers' Curiosity Levels in Terms of...

Academic Social Studies/Akademik Sosyal Araştırmalar, 9, Autumn, 1-14. https://doi.org/10.31455/asya.570845

Renner, B. (2006). Curiosity about people: The development of social curiositiy measure in adults. Journal of Personality Asssesment, 87(3), 305-316. https://doi.org/10.1207/s15327752jpa8703_11

Seçer, İ. (2015). Psikolojik Test Geliştirme ve Uyarlama Süreci. Anı Yayıncılık.

Şentürk, O. (2020). Investigation of Youth and Sports Provincial Directorate Employees' Participation in Recreational Activities in Terms of Questioning Skills, Curiosity and Discovery Levels. Unpublished master thesis, Düzce University.

Spielberger, C. D., \& Reheiser, E. C. (2009). Assessment of emotions: Anxiety, anger, depression, and curios. Applied Psychology: Health and Well-being, 1(3), 271-302. https://doi.org/10.1111/j.1758-0854.2009.01017.x

Spielberger, C. D., \& Butler, T. F. (1971). On the Relationship between Anxiety, Curiosity, and Arousal: A Working Paper. Unpublished manuscript, Florida State University.

Spielberger, C. D., Peters, R. A., \& Frain, F. (1976). The State-Trait Curiosity Inventory. Unpublished manual, University of South Florida, Tampa.

Tabachnick, B.G., \& Fidell, L.S. (2019). Çok Değişkenli İstatistiklerin Kullanımı. (Trans. M. Baloğlu). Nobel.

Turan, M. B. (2015). Investigation of Curiosity Levels and Relationship between Learning Styles of Students Studying Physical Education and Sport Teacher Departments. Unpublished Master Thesis, Erciyes University.

\section{EXTENDED ABSTRACT}

Effects of age, social class, gender studied program and universities over curiosity were also surveyed in the researches about curiosity (Acun, Kap1kiran and Kabasakal, 2013; Engelhard ve Monsaas, 1988; Ben-Zur ve Zeidner, 1988, Demirel ve Çoşkun, 2009; Litman and Spielberger, 2003; Şentürk, 2020; Kapıkıran and Kırmız1, 2019; Turan, 2015)

Neverthless, it was stated that mothers have protective attitudes in the lower social economic class families (Öğretir-Özçelik and Şıvkın, 2019). It is expresssed that individual's experiences and culture over curiosity is affected as well. (Kashdan, Rose and Fincham, 2004; Kashdan, et al., 2009; Lindholm, 2018; 
Elban, 2019). Within this scope problems of this research were planned as followings:

1.Is there any difference in the level of curiosity and exploring according to their genders of pre-service Turkish language teachers?

2.Is there any difference in the level of curiosity and exploring according to their social classes of pre-service Turkish language teachers?

3. Is there any difference in the level of curiosity and exploring according to their ages of pre-service Turkish language teachers?

4. Do pre-service Turkish language teachers 'curiosity and exploring differ from according to their mothers' education level?

5. Do pre-service Turkish language teachers 'curiosity and exploring differ from according to their fathers' education level?

6.Do pre-service Turkish language teachers' curiosity and level of exploring differ from according to their families' level of incomes?

7. Do pre-service Turkish language teachers 'curiosity and exploring differ from according to the geographical area they live?

This research is a study which was written in survey model aiming to analyze the curiosity and the level of exploring of pre-service Turkish language teachers.

It was discovered that students' curiosity and level of exploring scores don't differ according to their genders. In terms of gender, it wasn't determined any different in the research that Engelhard and Monsaas did (1988). In terms of gender, it wasn't found any difference in the level of curiosity and level of exploring of males in the first research Acun, Kapikıran and Kabasakal did (2013). Şentürk, (2020) wasn't found significant difference according to gender variable. In spit of that it was determined that level of curiosity and exploring of males is higher than the score of females in the research Acun, Kapıkıran, and Kabasakal did (2013).

And males' curiosity was explained by given more active roles for males. However, in terms of gender some discoveries made in support of males in many researches. (Kapıkıran and Kırmız1, 2019; Ben-Zur and Zeidner, 1988, Demirel and Çoşkun, 2009; Litman and Spielberger, 2003; Turan, 2015). It can be said different results can be obtained in the research of curiosity and exploring in terms of gender. The discovery obtained in the research can be evaluated in different results too. It was anaylzed that if the curiosity and exploring score differ or not according to class grade. It was determined that candidate teachers' curiosity and 
Investigation Pre-Service Turkish Language Teachers' Curiosity Levels in Terms of...

exploring score don't differ according to their class grade. It's clear the when it's analyzed related research's discovers about class grade parallel with the studies made before (Kapıkıran and Kırmız1, 2019; Turan, 2015). In terms of age of candidate Turkish language teachers' level of curiosity didn't differ. In terms of age of participations' level of curiosity differed in the Şentürk's research (2020). However, it is thought that the fact that there are participants from every age group in the mentioned study is an explanation for the different findings obtained in the two studies.

It was determined that candidate teachers' parents' education level and also families' economic level didn’t affect the curiosity level. Öğretir-Özçelik and Şıvkın (2019) stated that mothers from lower socio-economic families have protective attitudes. In this context it was though in this research that there's an effect of protective attitudes on curiosity, depending on socio-economic level. Based on this result, participants can end up protective attitudes of mothers in the later life or there's not any effect of protective attitudes on curiosity can be interpreted

In conclusion it was determined that there's not any effect of the geographical area students live in on curiosity. It's determined that the effect of the culture on curiosity. However, it can be explained by breaking the cultural influence in the place where it should not show this effect outside of geographical regions (Kashdan, Rose ve Fincham, 2004; Kashdan, vd., 2009). On the other hand, cultural effect can be related with the other dimensions of curiosity. 